\title{
Determining inland logistics service attributes: a case study of Chinese landlocked regions
}

\author{
Szu-Yu Kuo \\ Department of Shipping and Transportation Management, \\ National Penghu University of Science and Technology, Magong, Taiwan \\ Ching-Chiao Yang \\ Department of Shipping and Transportation Management, National Kaohsiung \\ University of Science and Technology, Kaohsiung, Taiwan, and \\ Po-Lin Lai \\ Department of International Logistics, \\ Chung-Ang University, Seoul, Republic of Korea
}

\begin{abstract}
Purpose - Recently, inland Chinese regions have become the major manufacturing base for most manufacturing firms. Accordingly, with this change, many shipping companies attempted to provide proper logistics service activities to maintain their business. Hence, this study aims to empirically examine the logistics service preference segments for Chinese landlocked regions from a manufacturer's perspective. By understanding these attributes, not only shipping companies but also logistics companies can provide proper service to their customers.

Design/methodology/approach - The preliminary logistics service attributes are determined using an interview and in-depth questionnaire with logistics experts from the local private and government sectors in southwest China and few international logistics coordinators. This study conducted importance-performance analysis (IPA) and used a customer dissatisfaction attitude index to evaluate the priorities for improving logistics service attributes. Cluster analysis is subsequently performed to group respondents on the basis of their factor scores.

Findings - Five crucial logistics service dimensions were identified by the factor analysis, namely, packing and storage, logistics supporting, logistics information, transportation planning and information inquiry. The results also revised the IPA model. The top five service attributes that needed to be improved were carrier selection, ship scheduling inquiry, route planning and inquiry, cargo receiving station and freight forwarding. By applying the factor analysis, this study reduced the 27 logistics attributes derived from the literature review to five underlying critical factors.

Originality/value - This study contributes to the inland logistics by investigating the preferences of manufacturers in Chinese landlocked regions. Moreover, in land logistics in China is lacking in the literature; hence, several important implications can be derived from this study's results.
\end{abstract}

Keywords Cluster analysis, Segmenting, Inland logistics, Landlocked region, Southwest China

Paper type Research paper

\section{Introduction}

China has established many bonded areas along the coastal cities to attract foreign investors after the economic opening in 1978. As extraordinary economic growth continues in China,

(C) Pacific Star Group Education Foundation. Licensed re-use rights only.

Determining inland logistics service

Received 25 September 2019 Revised 17 March 2020

1 April 2020

2 April 2020

Accepted 3 April 2020 
MABR

5,3 its merchandize trade values were the largest in the world in 2017. The total merchandize trade had increased from US\$37.6bn in 1980 to US $\$ 4,105 \mathrm{bn}$ in 2017, yielding a growth rate of 109.18 times (China Customs, 2017). Meanwhile, China's global GDP share was $18.2 \%$ in 2017 [International Monetary Fund (IMF), 2018]. Along with the economic growth, the demand for transportation and logistics has gradually emerged. By the end of 2016, the total logistics cost in China reached US $\$ 1,626.7 \mathrm{bn}$, with an annual rate of growth of $5.8 \%$. The total rate of logistics cost of GDP is $14.5 \%$ (China Federation of Logistics and Purchasing, 2016). These statistics indicate that the Chinese economy is expected to continue growing into the foreseeable future.

By providing a secure production and logistics environment, China has played the role of the world's factory. Recently, many corporations have been pondering moves to inland areas or expansion of their supply chains into landlocked regions in China such as Shanxi and Sichuan provinces because of the increasing cost (such as rent and wages) and seeking for the potential market. Consequently, the need for inland logistics has been growing and firms wishing to develop inland logistics markets are increasingly addressing the challenges posed by landlocked regions, including lack of seaports, poor infrastructure, transit delays, excessive logistics costs and costly bureaucratic procedures (Pérez-Salas et al., 2014; Hanif and Kaluwa, 2016). To continuously promote economic growth and inland development in China, more logistics network coverage will be expanded, particularly into southwest China (Kearney, 2010).

Inland logistics refers to a trend toward closer integration between maritime and inland transportation (Rodrigue et al., 2010). An outstanding inland logistics service can save transit time and cost. The time and cost reductions yield economic consequences, as producers gain access to inland markets, draw inputs/outputs from a large area and stimulate local production (Lean et al., 2014). As industrial clusters have been moved to inland, the number of new expressways, waterways, railways and airports is increasing for the large logistics demand. In particular, container transportation in China by inland waterway was estimated to grow to more than $12.6 \%$, with 26.99 million tons in 2017 (Ministry of Transportation, 2018). As a result, it is becoming a major task for the logistics service providers focused on the landlocked logistics market to offer practical services to meet inland demands.

Logistics is a strategic area that can provide a key competitive advantage and obtain higher requirements on service levels. Not only the prices but also the quality of service now rate as the most important requirement, followed by service reliability, flexibility and range of product offerings (Kearney, 2010). This implies that the logistics service needs to provide a more integrated, mature and higher-quality service. As companies expand rapidly in landlocked regions, the inland logistics requirements have expanded beyond the predictions; with broader national logistics activity coverage, consistent and correct market segments have become necessary.

Recent logistics research (Lean et al., 2014; Li et al., 2017) has suggested that logistics is now essential for economic development in China. These studies indicated that good logistics services that will benefit the economy include increased land/waterway transportation (Yang et al., 2016), an increased quantity of manufacturers (Shi et al., 2016) and better-quality logistics providers (Shi et al., 2016; Yang et al., 2016). Although these studies contributed new insights into logistics contexts in China, they focused only on coastal areas or large ports in China. Moreover, even though researchers had addressed the Belt and Road Initiative in terms of logistics (Li et al., 2017; Yang et al., 2017; Wei and Sheng, 2018), most studies focused on the supply side as the role of logistics infrastructure, not on the demand for logistics services. This study addresses this research gap as follows. 
First, to provide reliable shipping and logistics environment for attracting foreign direct investments and facilitating international trade, this research attempts to determine the major key logistics service attributes in Chinese landlocked regions from the customers' perspective.

Second, a traditional importance-performance analysis (IPA) model has been commonly applied to identify priorities for improving the service attributes. This study hoped to identify the accurate priorities for improving the types of inland logistics service attributes, instead of satisfaction. Thus, the shipper's perceived dissatisfaction with the inland logistics services was used to replace the "performance" variable. An IPA model with a dissatisfaction attitude (DA) index was performed to determine the priorities in improving logistics service attributes for Chinese landlocked regions.

Third, to the best of the authors' knowledge, few studies have examined inland logistics services from the customers' perspective in China. Moreover, understanding the logistics needs of different industries in landlocked regions in China, in detail, is still lacking. However, it is needed to help inland local governments or logistics service providers propose appropriate logistics policies and strategies for improving logistics competitiveness. Solving these questions will not only provide important management implications but also shed light on the new challenges and competitive advantages for logistics service providers. Thus, this research contributes to the application of the revised IPA model to identify priorities in improving landlocked logistics service attributes. Moreover, performing the exploratory factor analysis can identify the crucial logistics service dimensions in Chinese landlocked regions. Finally, by conducting cluster analysis, this study can gain an understanding of the preferences of logistics services for each group and further help decision-makers propose appropriate logistics service strategies for different logistics service preference groups. This can help logistics service providers and government authorities efficiently use and reallocate their resources.

\section{Inland logistics service attributes}

Logistics refers to "encompassing all activities and methods connected with supplying the military, including storage requirements, transport and distribution" (Krumwiede and Sheu, 2002). It is the management of all activities that facilitates movement and the coordination of supply and demand to make the best use of time and space (Steven, 1989). Thus, logistics is a process that adds value directly and meets customer requirements by providing services such as transportation, storage, customs clearance, inland transport, documentation, packaging and cargo tracking (Yang, 2012).

With the rising of labor and production costs, multinational enterprises have expanded their logistics networks to inland areas or their supply chains to landlocked regions in China to decrease logistics costs. Limited by their geographical locations, landlocked regions lack access to major ports and tend to lack adequate physical transportation and information systems. These regions are often poorly connected with the outside world and usually have slower development than coastal cities. They are broadly recognized as a major impediment to trade. Accordingly, inland logistics is increasingly important to the operation of businesses and the development of a nation's economy. It involves a closer integration between maritime and inland transportation (Rodrigue et al., 2010). In particular, inland logistics is a system that integrates the transportation of manufacturing in inland regions via land, river and sea with air transportation, ports and customer requirements to achieve efficient delivery of commodities (International Maritime Organization, 1991; Lu, 2004). 
MABR

5,3
In inland logistics, transportation and logistics requirements are the driving factor in logistics service (Chen et al., 2010; Hong and Liu, 2007). Previous studies have indicated the importance of transportation or logistics problems in the hinterlands (Monios, 2011; Notteboom and Rodrigue, 2005, 2009; Tran, 2011; Hanif and Kaluwa, 2016). For instance, Tran (2011) studied port selection on liner routes from an inland logistics perspective and found that a decrease in the number of vessel port calls brought the advantages of lower ship operation and inventory costs and port tariffs, but increased the inland transport cost. Meanwhile, Notteboom and Rodrigue (2009) examined logistics integration and network orientation between maritime and inland transport systems with a door-to-door channel approach. They indicated that a multiplication of transportation routes can meet the requirements of inland logistics and assist logistics operators to obtain the most benefit. From the perspective of seaport transportation operators, they not only provide port-to-port cargo delivery but also increase several more value-added services in logistics integration such as inland transportation, packing, labeling, warehousing, barcoding and carrier selection. Researchers also identified that major transport-logistics challenges in landlocked regions included poor infrastructure, coordination problems, logistic costs, delay in transit, corruption at borders and long distances to access the seaports (Buyonge, 2008; Pérez-Salas et al., 2014; Hanif and Kaluwa, 2016; Li et al., 2017).

Given constrained access to major ports, the concept of a dry port had been addressed for inland regions (Roso, 2007; Do et al., 2011; Cullinane et al., 2012; Wei and Sheng, 2018). A dry port serves as an intermodal transport hub in inland regions and integrates them with seaports and cross-border inland ports. Like a seaport, it can provide port services such as storage, consolidation, inspection and quarantine, customs clearance and issuance of bills of lading (Roso, 2007; Wei and Sheng, 2018). The dry port, thus can connect with seaports by providing efficient multimodal transport and customs clearance services, which in turn facilitate the movement and transshipment of sea cargo to inland regions. Constructing a dry port and providing logistics services can improve inland regions' logistical connectivity to the outside world. In particular, to attract foreign direct investments in landlocked regions, the Chinese Government needs to establish its own cross-border logistics networks.

An understanding of logistics requirements in landlocked regions can help decisionmakers propose appropriate policies and marketing strategies to meet manufacturers' needs. The aforementioned studies identified the crucial logistics attributes in inland regions. Moreover, an appraisal of prior studies on the types of logistics service indicated that the most common service attributes were related to transportation, warehousing, logistics value-added services, information and financial service. These service attributes used in prior studies included fleet management, warehouse management, freight consolidation, order fulfillment, carrier selection, logistics information systems, order processing, rate negotiation, freight bill payment, electronic transmission capability, intermodal services, customs clearance, picking and packaging, freight forwarding, inland transportation, cargo safety, cargo tracking and tracing, electronic transmission, insurance service and financial service (Dapiran et al., 1996; Murphy and Poist, 2000; Lai, 2004; Lu, 2004; Lieb and Bentz, 2004, 2005; Yang et al., 2009; Liu and Lyons, 2011; Rivera et al., 2016).

In addition, an expert interview with shipping and logistics executives in southwest China revealed that they need not only common logistics service (e.g. shipping or storage) but also other types of service such as cargo receiving stations, route planning and inquiry, special cargo arrangements and cargo surveys. This study, therefore, contends that previous studies and local logistics experts might have different service views, which can be used to segment markets and target marketing strategy. From a literature review and an 


\begin{tabular}{|c|c|}
\hline Measurement items & Previous research \\
\hline Bar coding operation & Lu (2003, 2004), Liu and Lyons (2011) \\
\hline $\begin{array}{l}\text { Cargo damage survey and } \\
\text { notarization }\end{array}$ & Outcome from interviews \\
\hline Cargo packing & $\begin{array}{l}\text { Murphy and Poist (1998, 2000), Lieb and Bentz (2004), Liu and Lyons (2011), } \\
\text { Rivera et al. (2016) }\end{array}$ \\
\hline Cargo receiving station & Outcome from interviews \\
\hline Cargo tracing & $\begin{array}{l}\text { Lai (2004), Lu (2003, 2004), Lieb and Bentz (2004, 2005), Lu and Yang (2006), } \\
\text { Liu and Lyons (2011) }\end{array}$ \\
\hline Carriers selection & Murphy and Poist (1998, 2000), Liu and Lyons (2011) \\
\hline $\begin{array}{l}\text { Container unpacking and } \\
\text { stuffing }\end{array}$ & $\begin{array}{l}\text { Murphy and Poist (1998, 2000), Lu (2003, 2004), Lieb and Bentz (2005), Liu and } \\
\text { Lyons (2011) }\end{array}$ \\
\hline Customer consultation & $\begin{array}{l}\text { Lai (2004), Lieb and Bentz (2004, 2005), Liu and Lyons (2011), Lu and Yang } \\
\text { (2006), Rivera } \text { et al. (2016) }\end{array}$ \\
\hline Electronic transmission & $\begin{array}{l}\text { Murphy and Poist (1998, 2000), Lu (2003, 2004), Lieb and Bentz (2004), Liu and } \\
\text { Lyons (2011) }\end{array}$ \\
\hline Export clearance inquiry & Lu (2003), Lu et al. (2006) \\
\hline Financial service & Murphy and Poist (1998, 2000), Liu and Lyons (2011), Lu et al. (2006) \\
\hline Freight bill payment & Murphy and Poist (1998, 2000), Lieb and Bentz (2005), Liu and Lyons (2011) \\
\hline Freight forwarding & Lai (2004), Lieb and Bentz (2005), Liu and Lyons (2011) \\
\hline $\begin{array}{l}\text { Frequency of sailings and } \\
\text { flights }\end{array}$ & $\mathrm{Lu}(2003)$ \\
\hline GPRS & Outcome from interviews \\
\hline Inventory management & $\begin{array}{l}\text { Murphy and Poist (1998, 2000), Lai (2004), Lieb and Bentz (2004, } \\
\text { 2005), Liu and Lyons (2011) }\end{array}$ \\
\hline $\begin{array}{l}\text { Logistics information } \\
\text { service }\end{array}$ & $\begin{array}{l}\text { Murphy and Poist (1998, 2000), Lai (2004), Lieb and Bentz } \\
\text { (2004), Liu and Lyons (2011) }\end{array}$ \\
\hline Market information service & $\mathrm{Lu}(2003,2004)$ \\
\hline $\begin{array}{l}\text { Multiple countries } \\
\text { distribution }\end{array}$ & $\begin{array}{l}\text { Murphy and Poist }(1998,2000), \mathrm{Lu}(2003,2004), \text { Liu and Lyons } \\
\text { (2011) }\end{array}$ \\
\hline Picking and packaging & Liu and Lyons (2011) \\
\hline Product returns and repairs & $\begin{array}{l}\text { Murphy and Poist (1998, 2000), Lu (2003, 2004), Lieb and Bentz (2005), and Liu } \\
\text { and Lyons (2011), Rivera et al. (2016) }\end{array}$ \\
\hline RFID & Liu and Lyons (2011) \\
\hline Route planning and inquiry & Outcome from interviews \\
\hline Ship scheduling inquiry & Lu (2003), Lu et al. (2006) \\
\hline Special cargo arrangement & Outcome from interviews \\
\hline Special cargo storage & Lu (2003, 2004), Liu and Lyons (2011) \\
\hline
\end{tabular}

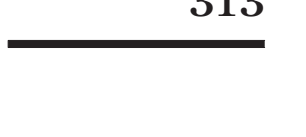




\section{MABR}

5,3

\section{4}

Figure 1.

Analytical steps

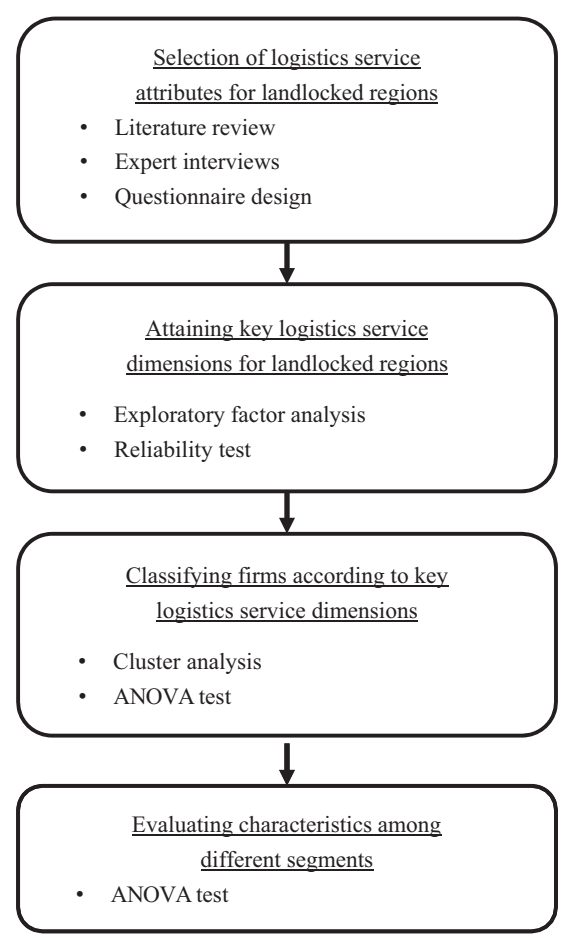

selection of scale items extends past solely the empirical issues and includes theoretical and practical considerations (Hair et al., 2010). All questions are based on previous studies and discussions with six logistics experts from manufacturing firms located in Chongqing Lianglu-Cuntan Free Trade Port Area, China. Six executives from the following industries were represented: food processing, high-tech, machinery and auto, chemical and manufacturing. Additionally, comments by three shipping experts whose company provides international logistics services were also referenced. In total, 27 logistics service attributes are selected in the survey questionnaire. Each logistics service attribute is assessed by a 5-point Likert scale ranging from $1=$ "strongly unimportant/dissatisfy" to $5=$ "strongly important/ satisfy."

The second step is conducting an exploratory factor analysis to identify the key factors underlying measurement items. Such an analysis can summarize a large number of types of logistics service into a smaller number of underlying dimensions and attain key logistics service factors. In addition, a reliability test with Cronbach's alpha values was conducted to examine the consistency and reliability of these service factors. The marketing strategy has long been considered very important in customer service, so a market should be segmented depending on customers' requirements $(\mathrm{Lu}, 2003)$. In the third step, cluster analysis was subsequently used to distinguish respondents' critical logistics services preferences. The Ward's method with the hierarchical technique using squared Euclidean distances was chosen to 
form clusters. The last step was carrying out an analysis of variance (ANOVA) to segment respondents' logistics services preferences, grouped in terms of the characteristics of their firms. All analyzes in the study were carried out using the SPSS 18.0 for Windows statistical packages.

Identifying priorities in improving inland logistics service attributes can help decisionmakers propose appropriate strategies for making such improvements and for meeting customers' requirements. A revised IPA model was, thus, carried out for this study (Hsu et al., 2015). The IPA model was originally developed by Martilla and James (1997) and contributes a two-dimensional plot with mean importance as the vertical axis and mean performance on the horizontal axis (Chen, 2014). Four quadrants with different managerial implications are divided in this plot by crosshairs. This study hopes to identify the priorities for improving the types of inland logistics service attributes, instead of satisfaction; hence, the shipper's perceived dissatisfaction with the inland logistics services was used to replace the "performance" variable.

The IPA technology allows facilitating a matrix-based evaluation of how the characteristics of the quadrants differ from each other. It can identify areas in which resources must be reallocated to improve logistics service quality (Chen, 2014). However, the original IPA model cannot provide accurate priorities for improving the logistics service attributes. To help logistics service providers efficiently use and reallocate their resources, following Hsu et al. (2015), this study applied a DA index to determine the priorities in improving logistics service attributes. Given that the higher importance and high dissatisfaction degree should be improved immediately, the DA index could be calculated by the following two equations, the DA index of the $i$ th service attributes is defined as follows:

$$
d_{i}=\omega_{i}^{I} \times \omega_{i}^{D}, i=1,2, \ldots \ldots \ldots, 27
$$

We normalize the $d_{i}, i=1,2, \ldots \ldots n$

$$
D A_{i}=\frac{d_{i}}{\sum_{i=1}^{27} d_{i}}, i=1,2, \ldots \ldots 27
$$

\subsection{Sampling}

This research empirically investigates and segments the requirements of inland logistics services for landlocked regions in southwest China from the shippers' perspective. A target sample of inland manufacturing firms in Chongqing Free Trade Port Area was selected and a questionnaire was mailed to 800 firms that were listed on Chongqing and Chengdu administration for industry and commence. Two rounds of the survey are conducted in this research. A total of 172 questionnaires were completed and returned with an overall response rate of $21.5 \%$.

\subsection{Bias issues}

The $t$-test was subsequently used to evaluate whether statistically significant differences exist between these two groups across the 27 measurement items. Result revealed no statistically significant mean differences among any of the items used in 
MABR

5,3

316

the estimated models, implying that non-response bias did not pose a problem in this study.

The data were obtained from single respondents; hence, a common method bias might have limited the accuracy of this analysis (Malhotra and Mackelprang, 2012). To look for possible common method bias within the data, the present study used Harman's single-factor test (Perols et al., 2013) to evaluate if a significant amount of variance was common across all items. Common method bias was not a significant problem with the data because the independent and dependent variables were loaded on different factors, with the first factor accounting for $26.90 \%$ of the total variance.

\subsection{Characteristics of respondents}

Most of the respondents hold senior managerial positions (30.7\%), followed by vicepresidential or above $(26.2 \%)$ and managerial $(23.7 \%)$ positions. In total, over $80 \%$ of the respondents were in managerial positions or above and were well-qualified to answer the questionnaire survey. Almost a third of the respondents $(29.7 \%)$ were from the mechanical and automotive industry, followed by traditional manufacturing $(18.0 \%)$, high-tech $(17.4 \%)$, mineral and chemical $(15.1 \%)$, food processing $(10.4 \%)$ and others $(9.3 \%)$. For the annual revenue, just over $70 \%$ of the respondents reported that their firms' annual revenue was US $\$ 100 \mathrm{~m}$ or less, whereas that of the $7.6 \%$ of the respondents' using firms was between US\$101m and US\$300m. Only $5.2 \%$ of the respondents' using firms had annual revenue of US\$301m or more.

Respondents are also asked to provide information about their logistics sourcing activities. Just over a third of the responding firms (34.3\%) outsourced their logistics activities to express delivery or logistics companies, followed by freight forwarding $(25.6 \%)$, customs brokers $(22.2 \%)$ and airline or shipping companies $(17.4 \%)$. In general, about a third $(27.0 \%)$ of the responding firms had a co-operative, long-term relationship with logistics companies, followed by customs brokers (18.3\%), freight forwarding (17.7\%), cargo freight stations (14.9\%), shipping companies (13.5\%) and airline companies $(7.8 \%)$. Specifically, most companies made an outsourcing contract with their logistics service providers for one year $(48.8 \%)$, followed by a half year $(22.1 \%)$, two years $(12.8 \%)$ and no tenure $(11 \%)$.

\section{Empirical analysis results}

\subsection{The priorities for improving for inland logistics service attributes}

The mean scores of importance and dissatisfaction for each logistics service attributes are shown in Table 2. The mean scores for importance and dissatisfaction were 3.94 and 1.73, respectively, which divided the matrix into the four quadrants. As shown in Figure 2, six logistics service attributes with high importance and high dissatisfaction fall into Quadrant A (concentrate management here), indicating that these service attributes should be improved immediately. Further, logistics service attributes with high importance and low dissatisfaction fall into Quadrant B (keep up the good work), indicating that managers should keep service quality up to sustain current advantages. Four logistics service attributes with low importance and high dissatisfaction fall into Quadrant C (low priority for management), indicating that these service attributes should be improved, but with low priority. Finally, eight logistics service attributes with low importance and high dissatisfaction fall into Quadrant D (possible overkill), indicating the managers might overkill these services.

Table 2 shows the DA index of each service this study applied to determine the priorities in improving for logistics service attributes. Of the six types in Quadrant A, the DA index 
indicates that the top five services that needed to be improved were carrier selection, ship scheduling inquiry, route planning and inquiry, cargo receiving stations and freight forwarding.

\subsection{Key logistics service dimensions in landlocked regions}

An exploratory factor analysis with varimax rotation was conducted to identify the key inland logistics service dimensions for Chinese landlocked regions. The Kaiser Meyer - Olkin (KMO) value should be over 0.8 for appropriate data analysis and factor loadings should be greater than 0.5 (Hair et al., 2010). KMO value indicates the degree to which each variable in a set is predicted without error by the other variables. Eigenvalues greater than one were used to decide on the number of factors (Iacobucci and Churchill, 2010). The initial factor analysis resulted in five factors that accounted for $67.089 \%$ of the total variance. Six items, namely, "logistics information service," "inventory management," "frequency of sailings and flights," "multiple countries distribution," "cargo tracing" and "radio frequency identification (RFID)" were found to load on two factors or to have a factor loading lower than 0.5 and were, therefore, eliminated in this study. Finally, five logistics service factors were

\begin{tabular}{|c|c|c|c|c|}
\hline \multicolumn{2}{|c|}{ Logistics service attributes } & \multirow{2}{*}{$\begin{array}{c}\begin{array}{c}\text { Importance } \\
\text { Mean }\end{array} \\
4.56\end{array}$} & \multirow{2}{*}{$\begin{array}{c}\begin{array}{c}\text { Dissatisfaction } \\
\text { Mean }\end{array} \\
1.56\end{array}$} & \multirow{2}{*}{$\frac{\mathrm{DA}(\%)}{3.89}$} \\
\hline A1 & Cargo damage survey and notarization & & & \\
\hline $\mathrm{A} 2$ & Customer consultation & 4.55 & 1.58 & 3.93 \\
\hline A3 & Cargo tracing & 4.51 & 1.67 & 4.12 \\
\hline $\mathrm{A} 4$ & Financial service & 4.46 & 1.60 & 3.90 \\
\hline A5 & Market information service & 4.45 & 1.56 & 3.79 \\
\hline A6 & Carrier selection & 4.40 & 1.82 & 4.38 \\
\hline A7 & Freight bill payment & 4.39 & 1.49 & 3.57 \\
\hline A8 & Export clearance inquiry & 4.33 & 1.67 & 3.95 \\
\hline A9 & Route planning and inquiry & 4.31 & 1.80 & 4.24 \\
\hline A10 & Freight forwarding & 4.28 & 1.77 & 4.14 \\
\hline A11 & Cargo receiving station & 4.27 & 1.80 & 4.20 \\
\hline A12 & Ship scheduling inquiry & 4.20 & 1.91 & 4.38 \\
\hline $\mathrm{A} 13$ & Frequency of sailings and flights & 4.12 & 1.68 & 3.78 \\
\hline A14 & Logistics information service & 4.03 & 1.60 & 3.52 \\
\hline A15 & Special cargo arrangement & 4.03 & 1.83 & 4.03 \\
\hline A16 & Inventory management & 3.87 & 1.68 & 3.55 \\
\hline A17 & Special cargo storage & 3.82 & 1.82 & 3.80 \\
\hline A18 & Container unpacking and stuffing & 3.79 & 1.63 & 3.38 \\
\hline A19 & Multiple countries distribution & 3.78 & 1.78 & 3.68 \\
\hline $\mathrm{A} 20$ & Picking and packaging & 3.76 & 1.85 & 3.80 \\
\hline A21 & Product returns and repairs & 3.72 & 1.77 & 3.60 \\
\hline $\mathrm{A} 22$ & Bar coding operation & 3.63 & 1.64 & 3.25 \\
\hline A23 & Cargo packing & 3.61 & 1.86 & 3.67 \\
\hline A24 & RFID & 3.10 & 1.68 & 2.85 \\
\hline A25 & Electronic commerce & 2.92 & 1.91 & 3.05 \\
\hline A26 & GPRS & 2.83 & 1.76 & 2.72 \\
\hline \multirow[t]{2}{*}{ A27 } & Electronic transmission & 2.71 & 1.92 & 2.84 \\
\hline & & 3.94 & 1.73 & \\
\hline
\end{tabular}

Note: Mean scores based on a five-point scale ( 5 = very important and dissatisfy; 1 = very unimportant/ satisfy)
Determining inland logistics service 
MABR

5,3

318

Figure 2.

Importance-

performance analysis of logistics service attributes

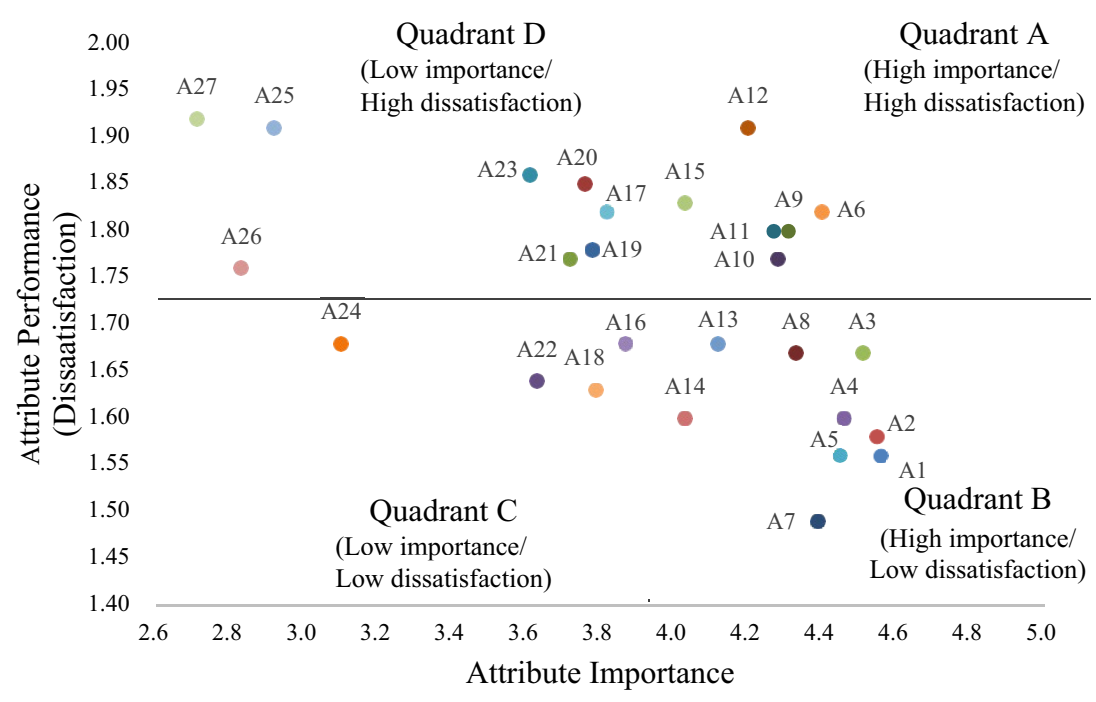

Quadrant D
Quadrant A

High importance/

\begin{tabular}{lccrrr}
\hline Logistics service attributes & Factor 1 & Factor 2 & Factor 3 & Factor 4 & Factor 5 \\
\hline Product returns and repairs & 0.838 & 0.045 & -0.036 & 0.180 & -0.017 \\
Cargo packing & 0.810 & 0.127 & -0.078 & 0.149 & -0.093 \\
Container unpacking and stuffing & 0.793 & 0.086 & 0.091 & 0.138 & 0.032 \\
Special cargo storage & 0.751 & 0.001 & 0.090 & -0.008 & 0.159 \\
Special cargo arrangement & 0.682 & 0.110 & 0.155 & -0.101 & 0.127 \\
Picking and packaging & 0.631 & 0.260 & 0.065 & 0.217 & 0.033 \\
Bar coding operation & 0.509 & 0.145 & -0.018 & 0.430 & -0.029 \\
Financial service & 0.105 & 0.804 & 0.031 & -0.100 & 0.219 \\
Market information service & 0.100 & 0.790 & 0.252 & 0.036 & -0.015 \\
Freight bill payment & 0.116 & 0.753 & 0.059 & -0.045 & 0.204 \\
Freight forwarding & 0.045 & 0.746 & -0.058 & 0.195 & 0.152 \\
Customer consultation & 0.195 & 0.728 & 0.229 & -0.059 & 0.007 \\
Cargo survey & 0.079 & 0.686 & 0.265 & -0.070 & 0.168 \\
Route planning and inquiry & 0.009 & 0.237 & 0.863 & -0.042 & 0.117 \\
Carriers selection & 0.071 & 0.103 & 0.848 & -0.033 & 0.092 \\
Cargo receiving station & 0.108 & 0.174 & 0.813 & 0.056 & -0.006 \\
Electronic transmission & 0.245 & -0.077 & -0.130 & 0.889 & -0.037 \\
Electronic commerce & 0.326 & -0.030 & -0.080 & 0.808 & 0.014 \\
GPRS & -0.093 & -0.009 & 0.238 & 0.678 & 0.302 \\
Ship scheduling inquiry & 0.109 & 0.255 & 0.077 & 0.166 & 0.857 \\
Export clearance inquiry & 0.068 & 0.355 & 0.117 & 0.014 & 0.814 \\
Eigenvalues & 5.831 & 3.649 & 1.865 & 1.805 & 1.119 \\
Percentage variance & 27.766 & 17.376 & 8.879 & 8.596 & 5.330 \\
Mean value of factor & 3.77 & 4.45 & 4.32 & 2.82 & 4.27 \\
Standard deviation of factor & 0.73 & 0.73 & 0.75 & 1.15 & 0.84 \\
Cronbach $\alpha$ & 0.864 & 0.873 & 0.847 & 0.782 & 0.823 \\
\hline
\end{tabular}

Table 3.

Inland logistics service dimensions formulation - factor analysis .

(n)


identified that accounted for $67.946 \%$ of the total variance. The final results of the factor analysis are shown in Table 3 and can be described as follows.

Factor 1 consisted of seven items, namely, "product returns and repairs," "cargo packing," "container unpacking and stuffing," "special cargo storage," "special cargo arrangement," "picking and packaging" and "bar coding operation." Product returns and repairs had the highest factor loading on this factor. As most items were related to cargo services, this factor was identified as "logistics value-added service." It accounted for $27.766 \%$ of the total variance.

Factor 2 is composed of six items, namely, "financial service," "cargo survey," "market information service," "freight bill payment," "freight forwarding," "customer consultation" and "cargo survey." Financial service had the highest loading on this factor. Because most of the items were related to supporting services, this factor was, therefore, named "logistics supporting services." It accounted for $17.376 \%$ of the total variance.

Factor 3 is composed of three items, namely, "route planning and inquiry," "carrier selection" and "cargo receiving station." Route planning and inquiry had the highest loading on this factor. As those items were related to planning service, this factor was, therefore, identified as "transportation planning service." It accounted for $8.879 \%$ of the total variance.

Factor 4 is composed of three items, namely, "electronic transmission," "electronic commerce" and "general packet radio service (GPRS)." As those items were related to information service, it was, therefore, identified as "logistic information service." Electronic transmission had the highest loading on this factor, which accounted for $8.596 \%$ of the total variance.

Finally, Factor 5 consisted of two items, namely, "ship scheduling inquiry" and "export clearance inquiry." Ship scheduling inquiry had the highest loading on this factor. As those items were related to information inquiry, this factor was, therefore, identified as "information inquiry service." It accounted for $5.330 \%$ of the total variance.

\subsection{Reliability test}

Before proceeding with cluster analysis, this study assessed the reliability of each dimension on the Cronbach's alpha coefficients for deciding whether the aforementioned factors were consistent and reliable. As shown in Table 4, all Cronbach's alpha values for all factors are shown in Table 4 and showed that all values were well above the suggested threshold of

\begin{tabular}{lcccccc}
\hline & \multicolumn{7}{c}{ Segments } & & & \\
Factor & 1 & \multicolumn{1}{c}{2} & \multicolumn{1}{c}{3} & $F$ ratio & $p$-value & Scheffe \\
\hline F1: Packing and storage service & $0.54^{\mathrm{a}}$ & 0.03 & -0.52 & 27.40 & $0.000^{* * *}$ & $(1,3)^{\mathrm{b}} ;(2,3)$ \\
F2: Logistics supporting service & -0.23 & -0.85 & 0.46 & 22.43 & $0.000^{* * *}$ & $(1,2) ;(1,3) ;(2,3)$ \\
F3: Transportation planning service & -0.08 & -0.10 & 0.10 & 0.68 & 0.508 & - \\
F4: Logistics information service & -0.39 & -0.30 & 0.46 & 17.56 & $0.000^{* * *}$ & $(1,3) ;(2,3)$ \\
F5: Information inquiry service & 0.43 & -1.87 & 0.13 & 98.07 & $0.000^{* * *}$ & $(1,2) ;(1,3) ;(2,3)$
\end{tabular}

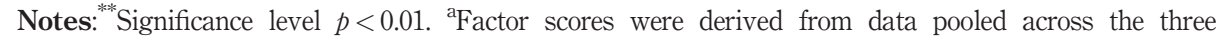
segments. The description of segments is based on factor scores with a mean of zero and standard deviation of one. ${ }^{\text {b}}$ Value in parentheses indicates a significant difference between segments at the $p<0.05$ significance level

Determining
inland logistics
service

319

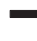


MABR

5,3

0.70, confirming a satisfactory level of reliability in this study (Hair et al., 2010). The mean for the five factors is between 2.82-4.45.

Table 4 also shows the respondents' aggregated perceptions of the importance of each key logistics service dimension. Logistics supporting service was perceived as the most important logistics service dimensions in landlocked regions by respondents, followed by transportation planning, information inquiry, logistics value-added and logistics information.

\subsection{Inland logistics service preferred groups}

With the limitation of resources, it is imperative for firms to realize customers' logistics service attributes preference segments, which in turn propose customized marketing strategies to meet customers' requirements. Thus, the market can be segmented into different groups based on customers' preference of different logistics service attributes. To segmenting logistics service market, a cluster analysis with a dendrogram using the Ward's approach was performed to segment the responding firms into various groups based on factor scores for each of the five factors. The result of the cluster analysis, in Table 4, suggested that three groups were identified: 73 in Segment 1, 22 in Segment 2 and 77 in Segment 3. The segmentation will be discussed in the next section.

One-way ANOVA is applied to examine factor differences across the three segments. Results, shown in Table 4, indicated that with the exception of transportation planning service, significant differences in factor scores were found between the three clusters at the $p<0.01$ significance level. A schffe test was subsequently used to measure all groups' factor scores and identify, which of the pairs show significance (Hair et al., 2010). The results indicated that differences in the four factors across the three segments can be identified. Factors 1, 2, 4 and 5 were found to significantly differ between Segments 1 and 3 and Segments 2 and 3, whereas Factors 2 and 4 were found to significantly differ between Segments 1 and 2 .

A comparison of factor score coefficients shows that Segment 1 had its highest centroid scores on Factor 1 (logistics value-added service) and Factor 5 (information inquiry service). Segment 3 had the highest positive scores on Factor 2 (logistics supporting service) and Factor 4 (logistics information service). However, Segment 2 had low or negative scores on all logistics service factors. Accordingly, the three segments were named "logistics value-added and information inquiry service

\begin{tabular}{lcccccc}
\hline $\begin{array}{l}\text { Type of firm of } \\
\text { respondents' firms }\end{array}$ & Firm & $\begin{array}{c}1 \\
(\%)^{\mathrm{a}}\end{array}$ & Firm & $\begin{array}{c}2 \\
(\%)\end{array}$ & Firm & $\begin{array}{c}3 \\
(\%)\end{array}$ \\
\hline $\begin{array}{l}\text { Food processing industry } \\
\text { High-tech industry }\end{array}$ & 7 & 9.6 & 1 & 4.5 & 10 & 13.0 \\
$\begin{array}{l}\text { Machinery and auto } \\
\text { industry }\end{array}$ & 16 & 21.9 & 4 & 18.2 & 10 & 13.0 \\
Metal and chemical industry & 20 & 27.4 & 6 & 27.3 & 25 & 32.5 \\
Manufacturing industry & 13 & 17.8 & 5 & 22.7 & 8 & 10.4 \\
Others & 10 & 13.7 & 4 & 18.2 & 17 & 22.1 \\
Total firms & 73 & 9.6 & 2 & 9.1 & 7 & 9.1 \\
Note: ${ }^{\text {a } \% \text { of the segment }}$ & & & 22 & & & \\
\end{tabular}

Table 5.

Characteristics of segments

Note: ${ }^{\text {a } \%}$ of the segment 
preferred group," "no particular preference group" and "logistics supporting and information service preferred group."

After segmenting the logistics service market, the logistics service providers need to target their niche market and formulate an effective service strategy based on their resources and capabilities. Hence, it is imperative for logistics service providers to know customers' requirements and realize the characteristics of customers in each segment. As shown in Table 5, each segment was cross-tabulated with the industry type of respondents' firms. For Segment 1, 27.4\% of the respondents' firms were in the machinery and auto industry, $17.8 \%$ were in the metal and chemical industry and $13.7 \%$ were in the manufacturing industry. Meanwhile those in Segment 2 were in the machinery and auto industry $(27.3 \%)$, followed by metal and chemical industry $(22.7 \%)$, high-tech industry $(18.2 \%)$ and manufacturing $(18.2 \%)$. The machinery and auto industry accounted for $32.5 \%$ of respondents' firms in Segment 3, followed by manufacturing industry $(22.1 \%)$, high-tech $(13.0 \%)$, food processing $(13.0 \%)$ and metal and chemical industry $(10.4 \%)$. Accordingly, the machinery and auto industry preferred logistics value-added and information inquiry service as well as logistics supporting and information services, whereas the high-tech industry and metal and chemical industry preferred logistics value-added and information inquiry service; food processing and manufacturing preferred logistics supporting and information services.

\section{Discussion and conclusion}

\subsection{Summary and findings}

This study contributes to the inland logistics by investigating the preferences of manufacturers in Chinese landlocked regions, specifically in Chengdu and Chongqing cities. The main findings are summarized as follow.

First, from the perspective of manufacturers, five important logistics service attributes from the perspective of manufacturers are cargo damage survey and notarization, customer consultation, cargo tracing, financial service and market information service are concluded. Unlike most of previous studies that emphasized the importance of cost and transportation-related service, this study found that cargo damage survey and notarization is rated as the most necessary services for shippers in landlocked regions. The risk and cost for landlocked logistics were perceived to be high; therefore, it is essential to provide cargo damage survey and notarization service for shippers when goods were suffered damage or lost in logistics operations. On the other hand, electronic data interchange, electronic commerce, ship scheduling inquiry, cargo packing and picking and packing were found to be the most unsatisfying types of service as perceived by respondents. Facing the logistics challenges such as poor infrastructure, distant access to seaports, the lack of reliability of transport systems and coordination problems (Pérez-Salas et al., 2014), logistics service providers need to establish an information system to enhance both internal and external information integration. This can effectively transfer data and share logistics information within the whole supply chain.

Second, given the results of the revised IPA model, the top five service attributes that needed to be improved were carrier selection, ship scheduling inquiry, route planning and inquiry, cargo receiving station and freight forwarding. The delays in transit and at border customs clearance were very common for landlocked regions. Thus, answering logistics information inquiry and providing consultation services on carrier selection, an alternative transportation mode, route planning and inquiry can improve the market position of 
MABR

5,3

\section{2}

logistics service providers. In addition, because of distant access to seaports and vast territory of southwest China, logistics service providers can adopt the hub-and-spoke concept to set up many cargo receiving stations for providing freight forwarding and consolidating services.

Finally, factor analysis was carried out and the 27 logistics attributes derived from the literature review were reduced to the following five underlying critical factors: logistics value-added service, logistics supporting service, transportation planning service, logistics information service and information inquiry service. Cluster analysis was subsequently conducted to classify the respondents into different logistics service preference groups on the basis of these factor scores. The three segments are the:

(1) logistics value-added and information inquiry services preference group;

(2) no particular preference group; and

(3) logistics supporting and information services preference group.

Results also indicated that there were significant differences in the four service factors across the three segments. Thus, the target markets with specific logistics services preferences can be identified by logistics service providers for proposing customized marketing strategies.

\subsection{Managerial implications}

In light of the fact that inland logistics in China is lacking in the literature, several important implications can be derived from the results. First, a strategy of appealing to all market segments usually leads to a fuzzy image in the marketplace. With the limitation of firms' resources, it is imperative for the logistics service providers to analyze customers' preference segments and modify their current strategy to more accurately meet customers' requirements. Correct marketing strategy can ensure there will be no conflicts between these different segments' real needs and can help logistics service providers gain competitive position in this dynamic marketplace. For instance, logistics supporting and information service is the greatest concern in the third segment. Given that logistics operating costs are higher and cargo is subject to various threats (Buyonge 2008), the following are essential to machinery and auto and metal and chemical industries: financial service, freight bill payment, cargo insurance, cargo damage survey and notarization, market information service, freight forwarding and logistics information inquiry and consultation services.

Second, logistics value-added service was the crucial issue to high-tech, machinery and auto and metal and chemical industries in the Segment 1. Logistics service providers must provide logistics value-added services such as product returns and repairs, packing, unpacking and stuffing, storage, picking and packaging and bar coding operation services for these industries. Moreover, in today's time-based competition marketplace, logistics information inquire was perceived important to high-tech, machinery and auto and metal and chemical industries. Thus, logistics service providers establish a platform for integrating whole supply chain partners. Through information integration, they can provide instant and accurate information such as cargo tracing, ship scheduling and export customs clearance for customers.

Third, the manufacturers preferred to outsource the logistics services to freight forwarders, express delivery companies and customs brokers. Logistics service providers should integrate the different functions of local logistics companies and processes to reduce 
the logistics cost. By providing integrated logistics service, they can attract more manufacturers willing to have long-term cooperation with them.

Finally, the results indicated that inland logistics services are most concerned with cargo damage survey and notarization, customer consultation and cargo tracking, which are different from prior studies focus on coastal areas. Most of the manufacturers in southwest China are import/export oriented. Information integration and warehousing, thus play an important role in inland logistics for facilitating the flow of goods and information. Furthermore, cargo is subject to various threats in the long-distance transit. It is, therefore, important to provide consultation service and cargo damage survey and notarization service for shippers when goods were damaged or lost in logistics operations.

\subsection{Limitations and direction for future research}

The findings of this research and its resulting implications are subject to limitations. First, this study was limited to examining the logistics service attributes based on the perceptions of manufacturers in a specific area (Chongqing and Chengdu). However, it is useful to compare them with inland logistics services in other parts of the world. Further research is suggested to collect data from other inland regions for comparison. Second, this study primarily focused on how manufacturing firms select logistics service in Chinese landlocked regions. The performance analysis is important for a firm to measure the efficiency of resource allocation and the outcome of corporate objectives. Another direction for future research might be to evaluate logistic performance from the shippers' point of view. Third, not only China has inland regions but also we conduct possible research in other region and countries such as Africa, Southeast Asia (Laos) and Mongolia. Fourthly, recently the service trans China rail has becoming common than before, we suggest considering this part in the future research. Finally, the issue of cause and effect such as the effect of logistics service on financial performance, was not addressed in this study. Structural equation modeling may be necessary to examine the outcomes of logistics service.

\section{References}

Buyonge, C. (2008), "Organisational design of customs in Sub-Saharan Africa: a critical evaluation", World Customs Journal, Vol. 2 No. 2, pp. 53-62.

Chen, K.Y. (2014), "Improving importance - performance analysis: the role of the zone of tolerance and competitor performance: the case of Taiwan's hot spring hotels", Tourism Management, Vol. 40, pp. 260-272.

Chen, H., Tian, Y., Ellinger, A.E. and Daugherty, P.J. (2010), "Managing logistics outsourcing relationships: an empirical investigation in China”, Journal of Business Logistics, Vol. 31 No. 2, pp. 279-299.

China Customs (2017), 2017 Annual Reports. General Administration of Customs People's Republic of China, China CustomsBeijing.

China Federation of Logistics and Purchasing (2016), "China logistics development report (2015-2016)", China Federation of Logistics and Purchasing, Beijing.

Cullinane, K., Bergqvist, R. and Wilmsmeier, G. (2012), "The dry port concept? Theory and practice", Maritime Economics and Logistics, Vol. 14 No. 1, pp. 1-13.

Dapiran, P., Lieb, R., Millen, R. and Sohal, A.S. (1996), "Third party logistics service usage by large Australian firms", International Journal of Physical Distribution and Logistics Management, Vol. 26 No. 10 , pp. $36-45$. 
MABR

5,3

Do, N.H., Nam, K.C. and Le, Q.L.N. (2011), "A consideration for developing a dry port system in Indochina area", Maritime Policy and Management, Vol. 38 No. 1, pp. 1-9.

Hair, J.F., Black, W.C., Babin, B.J., and Anderson, R.E. (2010), Multivariate Data Analysis, 7th ed., Prentice Hall, NJ.

Hanif, R. and Kaluwa, E. (2016), “Analysis of transport logistics challenges affecting freight forwarding operations in Malawi”, African Journal of Business Management, Vol. 10 No. 24, pp. 607-614.

Hong, J. and Liu, B. (2007), "Logistics development in China: a provider perspective", Transportation Journal, Vol. 46 No. 2, pp. 55-65.

Hsu, W.K., Yu, H.F. and Huang, S.H. (2015), "Evaluating the service requirements of dedicated container terminals: a revised IPA model with fuzzy AHP", Maritime Policy and Management, Vol. 42 No. 8, pp. 789-805.

Iacobucci, D. and Churchill, G.A. (2010), Marketing Research: Methodological Foundation, 10th ed., The Dryden Press, New York, NY.

International Monetary Fund (IMF) (2018), World Economic Outlook: Cyclical Upswing Structural Change, IMF, Washington, DC.

International Maritime Organization (1991), Port Logistics: Compendium for Model Course 5.02, IMO, London.

Kearney, A.T. (2010), China 2015: Transportation and Logistics Strategies. Marketing and Communication, A.T. Kearney Inc. New York, NY.

Krumwiede, D.W. and Sheu, C. (2002), “A model for reverse logistics entry by third-party providers”, Omega, Vol. 30 No. 5, pp. 325-333.

Lai, K.H. (2004), "Service capability and performance of logistics service providers", Transportation Research Part E: Logistics and Transportation Review, Vol. 40 No. 5, pp. 385-399.

Lean, H.H., Huang, W. and Hong, J. (2014), "Logistics and economic development: experience from China”, Transport Policy, Vol. 32, pp. 96-104.

Li, K.X., Jin, M., Qi, G., Shi, W. and Ng, A.K.Y. (2017), "Logistics as a driving force for development under the belt and road initiative - the Chinese model for developing countries", Transport Reviews, Vol. 38 No. 4, pp. 457-478.

Lieb, R. and Bentz, B.A. (2004), "The use of third-party logistics services by large American manufactures: the 2003 survey", Transportation Journal, Vol. 43 No. 3, pp. 24-34.

Lieb, R. and Bentz, B.A. (2005), "The use of third-party logistics services by large American manufactures: the 2004 survey", Transportation Journal, Vol. 44 No. 2, pp. 5-16.

Liu, C.L. and Lyons, A.C. (2011), "An analysis of third-party logistics performance and service provision", Transportation Research Part E: Logistics and Transportation Review, Vol. 47 No. 4, pp. 547-570.

Lu, C.S. (2003), "Market segment evaluation and international distribution centers", Transportation Research Part E: Logistics and Transportation Review, Vol. 39 No. 1, pp. 49-60.

Lu, C.S. (2004), "An evaluation of logistics services' requirements of international distribution centers in Taiwan", Transportation Journal, Vol. 43 No. 4, pp. 53-66.

Lu, C.S. and Yang, C.C. (2006), "Evaluating key logistics capabilities for international distribution center operators in Taiwan", Transportation Journal, Vol. 45 No. 4, pp. 9-27.

Lu, C.S., Lai, K.H. and Cheng, T.C.E. (2006), “Adoption of internet service in liner shipping: an empirical study of shippers in Taiwan”, Transport Reviews, Vol. 26 No. 2, pp. 189-206.

Malhotra, M.K. and Mackelprang, A.W. (2012), "Are internal manufacturing and external supply chain flexibilities complementary capabilities?”, Journal of Operations Management, Vol. 30 No. 3, pp. 180-200. 
Martilla, J.A. and James, J.C. (1997), “Importance-performance analysis”, Journal of Marketing, Vol. 41 No. 1, pp. 77-79.

Ministry of Transportation (2018), 2017 Transport Industry Development Statistics Bulletin, Beijing: Ministry of Transportation of the People's Republic of China.

Monios, J. (2011), "The role of inland terminal development in the hinterland access strategies of Spanish ports", Research in Transportation Economics, Vol. 33 No. 1, pp. 59-66.

Murphy, P.R. and Poist, R.F. (1998), "Third-party logistics usage: an assessment of propositions based on previous research", Transportation Journal, Vol. 37 No. 4, pp. 26-36.

Murphy, P.R. and Poist, R.F. (2000), "Third-party logistics: some user versus provider perspectives", Journal of Business Logistics, Vol. 21 No. 1, pp. 121-133.

Notteboom, T.E. and Rodrigue, J.P. (2005), "Port regionalization: towards a new phase in port development", Maritime Policy and Management, Vol. 32 No. 3, pp. 297-313.

Notteboom, T.E. and Rodrigue, J.P. (2009), "The future of containerization: perspectives from Maritime and inland freight distribution", GeoJournal, Vol. 74 No. 1, pp. 7-22.

Pérez-Salas, G., Jaimurzina, A., and Wilmsmeier, G. (2014), The Potential of AID fOR TRADE to Improve Infrastructure and Logistics Performance of Landlocked Developing Countries of Latin America, Economics Commission for Latin America and the Caribbean (UNECLAC), New York, NY.

Perols, J., Zimmermann, C.K. and Kortamann, S. (2013), "On the relationship between supplier integration and time-to-market”, Journal of Operations Management, Vol. 31 No. 3, pp. 153-167.

Rivera, L., Sheffi, Y. and Knoppen, D. (2016), "Logistics clusters: the impact of further agglomeration, training and firm size on collaboration and value-added service", International Journal of Production Economics, Vol. 179, pp. 285-294.

Rodrigue, J.P., Debrie, J., Fremont, A. and Gouvernal, E. (2010), "Functions and actors of inland ports: European and North American dynamics", Journal of Transport Geography, Vol. 18 No. 4, pp. 519-529.

Roso, V. (2007), "Evaluation of the dry port concept from an environmental perspective: a note", Transportation Research Part D: Transport and Environment, Vol. 12 No. 7, pp. 523-527.

Shi, Y., Zhang, A., Arthanari, T., Liu, Y. and Chen, T.C.E. (2016), "Third-party purchase: an empirical study of third-party logistics providers in China", International Journal of Production Economics, Vol. 171 No. 2, pp. 189-200.

Steven, G.C. (1989), "Integrating the supply chain", International Journal of Physical Distribution and Logistics Management, Vol. 19 No. 8, pp. 3-8.

Tran, N.K. (2011), "Studying port selection on liner routes: an approach from logistics perspective", Research in Transportation Economics, Vol. 32 No. 1, pp. 39-53.

Wei, H. and Sheng, Z. (2018), "Logistics connectivity considering import and export for chinese inland regions in the $21^{\text {st }}$-century Maritime silk road by dry ports", Maritime Policy and Management, Vol. 45 No. 1, pp. 53-70.

Yang, C.C. (2012), "Assessing the moderating effect of innovation capability on the relationship between logistics service capability and firm performance for ocean freight forwarders", International Journal of Logistics Research and Applications, Vol. 15 No. 1, pp. 53-69.

Yang, C.C., Marlow, P.B. and Lu, C.S. (2009), "Assessing resources, logistics service capabilities, innovation capabilities and the performance of container shipping services in Taiwan", International Journal of Production Economics, Vol. 122 No. 1, pp. 4-20.

Yang, D., Pan, K. and Wang, S. (2017), "On service network improvement for shipping lines under the one belt one road initiative of China", Transportation Research Part E: Logistics and Transportation Review, Vol. 117, pp. 82-95. 
MABR

5,3
Yang, Q., Zhao, X., Yeung, H.Y.J. and Liu, Y. (2016), "Improving logistics outsourcing performance through transactional and relational mechanisms under transaction uncertainties: evidence from China", International Journal of Production Economics, Vol. 175, pp. 12-23.

\section{Further reading}

Sheu, J.B. and Kundu, T. (2017), "Forecasting time-varying logistics distribution flows in the one BeltOne road strategic context", Transportation Research Part E, Vol. 117, pp. 5-22.

\section{Corresponding author}

Po-Lin Lai can be contacted at: polin@cau.ac.kr

For instructions on how to order reprints of this article, please visit our website: www.emeraldgrouppublishing.com/licensing/reprints.htm

Or contact us for further details: permissions@emeraldinsight.com 